\title{
Daily Spiritual Experience dan Kesejahteraan Psikologis pada Istri yang Kehilangan Pasangan karena Meninggal Dunia
}

\author{
Annisa Parila \\ Endah Puspita Sari \\ Wardah Roudhotina
}

\author{
Program Studi Psikologi, Fakultas Psikologi dan Ilmu Sosial Budaya \\ Universitas Islam Indonesia, Yogyakarta
}

\begin{abstract}
The purpose of this study is to determine the correlation between psychological wellbeing and daily spiritual experience among widow. There were 45 participants from five villages in Kecamatan Rambah, Rokan Hulu, Riau. Psychological well-being scale was used to collect data and adapted from psychological well being scales by Ryff (1995). Daily spiritual experience scale was used and adapted from daily spiritual experience scales by Underwood and Teresi (2002). The result showed that there is a positive correlation between psychological well-being and daily spiritual experience among widow $(r=0.389, \mathrm{p}<0.01)$.
\end{abstract}

Keywords: psychological well-being, daily spiritual experience, widow

Abstrak. Penelitian ini bertujuan untuk mengetahui hubungan antara kesejahteraan psikologis dan daily spiritual experience pada istri yang kehilangan pasangan karena meninggal dunia. Responden pada penelitian ini berjumlah 45 orang di lima desa di Kecamatan Rambah, Rokan Hulu, Riau. Hipotesis dalam penelitian ini adalah adanya hubungan positif antara kesejahteraan psikologis dan daily spiritual experience pada istri yang kehilangan pasangan karena meninggal dunia. Skala kesejahteraan psikologis mengadaptasi psychological well being scales (PWBS) yang dikembangkan oleh Ryff (1995), sedangkan skala daily spiritual experience mengadaptasi daily spiritual experience scales (DSES) dari Underwood dan Teresi (2002). Hasil penelitian menunjukkan nilai $p=0,004(p<0,01)$ dan nilai $r=0,389$ yang artinya terdapat hubungan positif antara daily spiritual experience dan kesejahteraan psikologis pada istri yang kehilangan pasangan karena meninggal dunia.

Kata kunci: kesejahteraan psikologis, daily spiritual experience, istri

Dalam tahapan perkembangan manusia, periode dewasa tengah merupakan salah satu masa yang akan dilalui setiap individu. Santrock (2003) menjelaskan bahwa periode dewasa tengah terjadi dalam rentang usia 35 tahun hingga 55 tahun dan merentang hingga 65 tahun. Masa dewasa tengah adalah masa dimana individu cenderung penuh dengan pekerjaan yang kreatif dan bermakna, serta munculnya berbagai permasalahan seputar keluarga (Santrock, 2005).

Terdapat banyak permasalahan yang muncul dalam keluarga pada periode dewasa tengah, salah satunya adalah kehilangan pasangan hidup karena meninggal dunia. Nalungwe (2009) menyebutkan bahwa seorang

Korespondensi: Endah Puspita Sari. Email : endah_puspita_sari@uii.ac.id 
istri memiliki probabilitas kehilangan pasangan yang lebih tinggi karena biasanya wanita memiliki harapan hidup yang lebih lama dibanding pria dan wanita cenderung menikah dengan pria yang lebih tua darinya. Hal ini juga dibuktikan dengan jumlah istri yang kehilangan pasangan dibandingkan dengan suami yang ditinggalkan istri karena meninggal dunia adalah 5 banding 1 (Laksono, 2008). Artinya, jumlah istri yang kehilangan pasangan hidup lima kali lebih banyak dibandingkan suami yang kehilangan pasangan hidupnya.

Seorang istri yang harus kehilangan suami disebabkan kematian sering berada dalam situasi yang tidak mudah. Ketika mendapati suami meninggal dunia, maka istri akan mengalami perasaan terkejut, penolakan, tidak berdaya, kesedihan dan kesepian dalam periode duka (Nalungwe, 2009). Castello (Nalungwe, 2009) menjelaskan bahwa perasaan sedih yang muncul setelah kematian pasangan dapat memudar seiring berjalannya waktu. Walaupun demikian, peristiwaperistiwa besar dalam hidup seperti kehilangan juga dapat memicu terjadinya gangguan di satu rutinitas normal. Istri yang kehilangan suaminya masih harus berjuang menjalankan tanggung jawab dan aktivitas yang sebelumnya dapat dibagi dan dilakukan bersama suami, diantaranya tanggung jawab atas pemenuhan kebutuhan ekonomi dan rumah tangga, hubungan sosial maupun hal-hal yang berkaitan dengan masa depan anak (Holmes \& Rahe dalam Wilcox et al., 2003).
Kematian pasangan dinilai sebagai salah satu peristiwa hidup yang paling menekan dalam kehidupan manusia (Amster \& Krauss dalam Wilcox et al., 2003). Istri yang kehilangan pasangan hidup karena meninggal dunia rentan mengalami masalah pada fungsi sosial, perasaan depresi maupun kesehatan mental secara keseluruhan (Wilcoxs et al., 2003). Doshi dan Yogesh (2013) menjelaskan bahwa depresi berpengaruh negatif terhadap kesejahteraan psikologis seseorang. Seseorang yang mengalami depresi atau memiliki tingkat depresi yang tinggi akan mengalami masalah kesejahteraan psikologis.

Istri yang kehilangan pasangan hidup karena meninggal dunia dapat menjadikan halhal positif dalam diri dan lingkungan sekitar, seperti dukungan sosial dan perasaan selalu mendapat perlindungan dan bantuan sebagai pendorong dalam menjalani hidup dengan baik bersama anak-anak sehingga dapat mencapai hidup harmonis dan bahagia. Sebaliknya, apabila istri tidak berhasil bangkit dan menjadikan hal-hal positif dalam dirinya dan lingkungan sekitar sebagai pendorong dalam menjalankan aktivitas setelah kehilangan suami serta terus menerus berada dalam kesedihan, kekecewaan dan kehampaan diri, maka dapat berakibat munculnya perasaan tidak bahagia (Wilcox et al., 2003). Kebahagian dan ketidakbahagiaan disebut juga kesejahteraan psikologis.

Menurut Ryff dan Keyes (1995) kesejahteraan psikologis didefinisikan sebagai 
hasil penilaian atau evaluasi seseorang terhadap dirinya yang merupakan evaluasi atas pengalaman-pengalaman dalam hidupnya. Individu yang memiliki kesejahteraan psikologis yang tinggi, akan memiliki penerimaan diri yang baik, mampu membangun hubungan positif dengan orang lain, memiliki keterampilan dalam mengkontrol dan menguasai lingkungan di sekitarnya, mampu merealisasikan potensi dalam diri dan memiliki tujuan dan makna hidup (Ryff \& Keyes, 1995). Individu dengan kesejahteraan psikologi yang tinggi, maka sama halnya dengan individu yang dapat befungsi secara penuh dalam hidupnya (Ryff \& Keyes, 1995). Sementara itu, apabila seseorang memiliki kesejahteraan psikologis yang rendah, akan mengalami masalah pada dimensidimensi kesejahteraan psikologis, seperti memiliki penerimaan diri yang rendah, kurang mampu menguasai lingkungan disekitarnya, bahkan tidak memiliki tujuan dan makna hidup (Ryff \& Keyes, 1995).

Terdapat beberapa faktor yang mempengaruhi kesejahteraan psikologis seseorang. Faktor-faktor tersebut diantaranya adalah usia, jenis kelamin, budaya, dukungan sosial, status sosial dan ekonomi, spiritualitas dan religiusitas dan lain-lain (Ryff ,1989). Pada penelitian ini, peneliti berfokus pada spiritualitas dan religiusitas sebagai salah satu faktor yang menarik untuk diteliti. Definisi spiritualitas memiliki cakupan yang luas, sehingga mengakibatkan kurangnya kejelasan mengenai apa yang sebenarnya ingin diukur (Underwood \& Teresi, 2002). Cakupan definisi yang luas mendorong beberapa tokoh untuk fokus pada lingkup-lingkup yang lebih kecil dari aspek spiritualitas. Salah satu dimensi utama spiritualitas yang menarik untuk dipahami lebih dalam dan diharapkan dapat memberikan pengaruh yang positif terhadap kesejahteraan psikologis adalah pengalaman spiritual seharihari atau yang lebih dikenal dengan istilah daily spiritual experience.

Daily spiritual experience didefinisikan sebagai persepsi individu terhadap pengalaman spiritual yang terjadi terkait dengan hal-hal yang transenden dan makna kehidupan, berupa perasaan terhubung dengan Tuhan, senantiasa merasakan kerinduan, dukungan, dan kasih sayang yang transenden, dan adanya perasaan kagum, murah hati, bersyukur, dan keutuhan dengan adanya Tuhan (Underwood \& Teresi, 2002). Daily spiritual experience dapat memberikan kontribusi positif pada kesehatan mental dan kesejahteraan psikologis seseorang (Underwood \& Teresi, 2002). Bukti awal juga menujukkan bahwa daily spiritual experience memiliki keterkaitan dengan peningkatan kualitas hidup, status psikososial yang positif dan penurunan konsumsi alkohol (Underwood \& Teresi, 2002). Penelitian lain yang dilakukan oleh Einofl (2013) juga mengemukakan bahwa daily spiritual exsperience berkontribusi positif terhadap perilaku prososial seseorang. Perilaku sosial dapat mempengaruhi salah satu dimensi kesejahteraan psikologis, yaitu hubungan positif 
dengan orang lain..

Istri yang kehilangan suami karena meninggal dunia dituntut untuk dapat kembali beradaptasi dengan situasi baru tanpa hadirnya suami. Hal ini tentu akan memunculkan permasalahan-pemasalahan baru yang dapat menghambat seorang istri mencapai kebahagiaan. Namun, persepsi berupa pengalaman spiritual yang dirasakan dapat menjadi sumber kekuatan bagi istri yang kehilangan pasangan hidupnya, baik dalam kehidupan sehari-hari maupun kehidupan pasca kematian suami. Rasa adanya kasih sayang dan dukungan dari yang transenden dapat membantu seseorang terhindar dari perasaan kesepian dan tidak berdaya. Selain itu, adanya perasaan senantiasa terhubung dan syukur kepada Tuhan dapat membantu seseorang dalam melawan situasi-situasi menekan (Underwood \& Teresi, 2002). Begitu juga dengan istri yang kehilangan pasangan hidup. Pengalaman-pengalaman spiritual yang senantiasa dirasakan sehari-hari akan membantu istri dengan mudah beradaptasi dan mampu menyelasaikan masalah-masalah baru yang muncul pasca kematian suami, sehingga memiliki tujuan hidup yang lebih terarah dan memperoleh kebahagiaan.

Berdasarkan uraian di atas, peneliti tertarik untuk meneliti secara empiris kaitan antara daily spiritual experience dan kesejahteraan psikologis pada istri yang kehilangan pasangan hidup akibat meninggal dunia. Selanjutnya, hipotesis pada penelitian ini adalah terdapat hubungan positif antara daily spiritual experience dan kesejahteraan psikologis pada istri yang kehilangan pasangan hidup akibat meninggal dunia. Semakin tinggi daily spiritual experience istri yang kehilangan pasangan hidupnya karena meninggal dunia, diharapkan akan semakin tinggi pula kesejahteraan psikologisnya. Sebaliknya, semakin rendah daily spiritual experience istri, maka akan semakin rendah pula kesejahteraan psikologisnya.

\section{Metode}

\section{Rancangan penelitian}

Penelitian ini menggunakan studi korelasional untuk mengukur hubungan antara daily spiritual experience dan kesejahteraan psikologis pada istri yang kehilangan pasangan hidup akibat meninggal dunia. Daily spiritual experience merupakan variabel bebas dan kesejahteraan psikologis merupakan variabel tergantung.

\section{Subjek penelitian}

Subjek dalam penelitian ini adalah istri yang kehilangan pasangan hidup (suami) karena meninggal dunia, dan berada dalam rentang usia 45 tahun hingga 55 tahun.

\section{Metode pengambilan data}

Alat pengumpul data yang digunakan dalam penelitian ini adalah skala. Skala merupakan alat ukur yang terdiri dari 
sekumpulan pertanyaan atau pernyataan dan digunakan untuk mengungkapkan konstruk psikologis yang menggambarkan aspek kepribadian individu (Azwar, 2009). Adapun skala yang digunakan dalam penelitian ini adalah skala kesejahteraan psikologis yang mengadaptasi dari psychological well being scales (PWBS) oleh Ryff (1995). Skala kesejahteraan psikologis terdiri atas 18 item, 10 pernyataan favorable dan 8 pernyataan unfavorable. Sementara itu, skala daily spiritual experience mengadaptasi daily spiritual experience scales (DSES) dari Underwood dan
Teresi (2002). Skala daily spiritual experience terdiriatas 16 pernyataanfavorable.

\section{Analisis data}

Metode analisis data dalam penelitian ini adalah analisis statistik menggunakan SPSS for Windows versi 21. Uji korelasi dilakukan menggunakan teknik product moment dari Pearson. Sebelum diuji menggunakan teknik korelasi product moment, terlebih dahulu dilakukan uji asumsi yang terdiri dari uji normalitas dan uji linearitas.

Tabel 1. Distribusi Aitem Skala Kesejahteraan Psikologis

\begin{tabular}{lrrrr}
\hline Aspek & \multicolumn{3}{c}{ Butir Favorable } & \multicolumn{2}{c}{ Butir Unfavorable } \\
\cline { 2 - 5 } & Nomor Butir & Jumlah & Nomor Butir & Jumlah \\
\hline Penerimaan diri & 7,16 & 2 & 3 & 1 \\
Hubungan positif dengan orang lain & 12 & 1 & 5,10 & 2 \\
Penguasaan lingkungan & 2,18 & 2 & 11 & 1 \\
Kemandirian & 9,17 & 2 & 1 & 1 \\
Pertumbuhan pribadi & 4,12 & 2 & 14 & 1 \\
Tujuan hidup & 15 & 1 & 8,6 & 2 \\
Total & & 10 & & 8 \\
\hline
\end{tabular}

Table 2. Distribusi Aitem Skala Daily Spiritual Experience

\begin{tabular}{lrr}
\hline \multirow{1}{*}{ Aspek } & \multicolumn{2}{c}{ Butir Favorable } \\
\cline { 2 - 3 } & Nomor Butir & Jumlah \\
\hline Connection with the transcendent & 1,2 & 2 \\
Sense of support from the & $4,5,9,10,7,8$ & 6 \\
ranscendent & 6 & \\
Sense of wholeness & 3 & 1 \\
Transcendent sense of self & 11 & 1 \\
Sense of awe & 12 & 1 \\
Sense of gratitude & 57 & 1 \\
Sense of compassion & 58 & 1 \\
Sense of mercy & $59,5^{\circ}$ & 2 \\
Longing for the transcendent & & 16 \\
Total & & \\
\hline
\end{tabular}




\section{Hasil}

\section{Deskripsi subjek penelitian}

Berdasarkan data-data yang telah terkumpul dalam penelitian ini, maka diperoleh data dari subjek yang keseluruhannya merupakan istri yang kehilangan pasangan hidup karena meninggal dunia. Gambaran umum mengenai subjek penelitian berdasarkan data-data pada tabel 3.
13 orang $(28,88 \%)$, dan subjek yang berada dalam rentang usia 52-55 tahun berjumlah 15 orang dengan persentase sebesar $33,33 \%$.

Berdasarkan tabel 4, diketahui bahwa subjek penelitian dengan pendidikan terakhir S1 berjumlah 3 orang (8,88\%), tidak terdapat subjek dengan pendidikan terakhir D3 (0\%). Sementara itu, subjek penelitian dengan pendidikan terakhir tingkat SMA berjumlah 4 orang $(8,88 \%)$ dan subjek dengan pendidikan terakhir tingkat SMP

Tabel 3. Deskripsi Subjek Penelitian Berdasakan Usia

\begin{tabular}{lrrr}
\hline Faktor & Kategori & Jumlah & Persentase \\
\hline Usia & $45-48$ & 17 & $37,77 \%$ \\
& $48-51$ & 13 & $28,88 \%$ \\
& $52-55$ & 15 & $33,33 \%$ \\
Total & & 45 & $100 \%$ \\
\hline
\end{tabular}

Ŝż Y $\hat{U}_{F}$. Deskripsi Subjek Penelitian Berdasakan Pendidikan Terakhir

\begin{tabular}{lrrr}
\hline Faktor & $\dot{\mathrm{G}} \dot{\mathrm{Z}}^{\mathrm{V}} \mathrm{YL} \hat{Y}^{\mathrm{h}} \breve{\mathrm{o}}$ & Jumlah & Persentase \\
\hline Pendidikan terakhir & S1 & 4 & $8,88 \%$ \\
& D3 & 0 & $0 \%$ \\
& SMA & 4 & $8,88 \%$ \\
& SMP & 9 & $20 \%$ \\
& SD & 25 & $55,55 \%$ \\
Total & Lainnya & 3 & $6,66 \%$ \\
& & 45 & $100 \%$ \\
\hline
\end{tabular}

Berdasarkan tabel 3, diketahui bahwa subjek penelitian yang berada dalam rentang usia 45-48 tahun berjumlah 17 orang dengan persentase sebesar $37,77 \%$, subjek yang berusia antara 48-51 tahun berjumlah berjumlah 9 orang (20\%). Subjek dengan pendidikan terakhir terbanyak adalah pada tingkat SD yang berjumlah 25 orang $(55,55 \%)$, dan subjek yang berada pada kategori lainnya sebanyak 3 orang $(6,66 \%)$. 
Ŝż Y $\hat{U}_{G}$. Deskripsi Subjek Penelitian Berdasarkan Pekerjaan

\begin{tabular}{clrr}
\hline \multicolumn{1}{c}{ Faktor } & \multicolumn{1}{c}{$\dot{\mathrm{G}} \dot{\mathbf{Z}}^{\mathrm{v}} \mathrm{YL} \hat{\mathrm{Y}}^{\mathrm{h}} \breve{O}$} & Jumlah & Persentase \\
\hline Pekerjaan & PNS & 4 & $8,88 \%$ \\
& Pegawai Swasta & 1 & $2,22 \%$ \\
& Wirausaha & 7 & $15,55 \%$ \\
& Ibu Rumah Tangga & 13 & $28,88 \%$ \\
Total & Petani & 20 & $44,44 \%$ \\
& & & $100 \%$ \\
\hline
\end{tabular}

Berdasarkan uraian tabel 5, menunjukkan bahwa subjek yang bekerja sebagai pegawai negeri sipil berjumlah 4 orang $(8,88 \%)$ dan pegawai swasta 1 orang $(2,22 \%)$. Subjek yang berwirausaha berjumlah 7 orang $(15,55 \%)$, sedangkan subjek yang berada dalam kategori lainnya ibu rumah tangga berjumlah 13 orang $(28,88 \%)$. Terakhir adalah subjek yang bekerja sebagai petani berjumlah 20 orang $(44,44 \%)$. Dari data di atas, dapat disimpulkan bahwa subjek terbanyak adalah subjek yang bekerja sebagai petani, dengan persentase sebesar 44,44\%.

\section{Deskripsi data penelitian}

Berdasarkan hasil perhitungan yang dilakukan terhadap data yang diperoleh, maka dapat diketahui fungsi statistik mengenai skor hipotetik yang meliputi skor maksimal, skor minimal, rerata (mean), dan standar deviasi pada masing-masing skala. Deskripsi data penelitian secara umum dapat dilihat pada tabel 6 .

Berdasarkan deskripsi data penelitian yang telah diuraikan tabel 6, dapat dihitung sebaran hipotetik dari skor kesejahteraan psikologis dan dan daily spiritual experience dilakukan penguraian keadaan kelompok subjek penelitian dapat dilihat pada tabel 7 .

Berdasarkan tabel 7, subjek dengan kesejahteraan psikologis dalam kategori

Tabel 6. Deskripsi Data Penelitian

\begin{tabular}{lllll}
\hline \multirow{2}{*}{ Variabel } & \multicolumn{4}{c}{ Hipotetik } \\
\cline { 2 - 5 } & Min & Maks & Mean & SD \\
\hline Kesejahteraan Psikologis & 11 & 66 & 38,5 & 9,16 \\
Daily Spiritual Experience & $5^{0}$ & 94 & 56 & 13 \\
\hline
\end{tabular}

$\hat{S} \dot{z ̇} \underline{Y}_{\mathrm{I}}$. Kategori Subjek Berdasarkan Skor Kesejahteraan Psikologis

\begin{tabular}{ccrr}
\hline Skor & $\dot{\mathrm{G}} \dot{z}^{\mathrm{V}}{ }_{\mathrm{YL}} \hat{\mathrm{Y}}^{\mathrm{h}} \breve{\mathrm{O}}$ & Frekuensi & Persentase \\
\hline $\mathrm{X}<29,3$ & Rendah & 1 & $2,23 \%$ \\
$29,3=\mathrm{X}<47,7$ & Sedang & 14 & $31,11 \%$ \\
$\mathrm{X}>47,7$ & Tinggi & 30 & $66,67 \%$ \\
Total & & 45 & $100 \%$ \\
\hline
\end{tabular}


rendah berjumlah 1 orang dengan dengan persentase sebesar 2,23\%, selanjutnya 14 subjek masuk dalam kategori sedang dengan persentase sebesar $31,11 \%$, dan subjek yang masuk kedalam kategori tinggi sebanyak 30 orang atau sebesar 66,67\%.Dengan demikian, dapat disimpulkan bahwa kesejahteraan psikologis pada subjek istri yang kehilangan pasangan hidup karena meninggal dunia dalam penelitian ini sebagian besar berada pada kategori tinggi, yaitu 30 orang dengan persentase sebesar $66,67 \%$. orang dengan prosentasi sebesar $66,67 \%$. Dapat disimpulkan bahwa sebagian besar dari subjek penelitian ini memiliki tingkat daily spiritual experience yang tinggi.

\section{Hasil uji asumsi}

Uji asumsi yang dilakukan dalam penelitian ini adalah uji normalitas dan linieritas. Hal ini dilakukan agar kesimpulan yang didapat tidak menyimpang dari kebenaran yang seharusnya.

Tabel 8. Kategori Subjek Berdasarkan Skor Daily Spiritual Experience

\begin{tabular}{llrr}
\hline Skor & Kategori & Frekuensi & Persentasi \\
\hline$X<42,6$ & Rendah & 0 & $0 \%$ \\
$42,6=X<69,6$ & Sedang & 15 & $33,33 \%$ \\
$X>69,6$ & Tinggi & 30 & $66,67 \%$ \\
Total & & 45 & $100 \%$ \\
\hline
\end{tabular}

Ŝż Y $\hat{U}_{K}$. Hasil Uji Normalitas

\begin{tabular}{lcl}
\hline Variabel & $p$ & Keterangan \\
\hline Kesejahteraan Psikilogis & 0,486 & Normal \\
Daily Spiritual Experience & 4,956 & Normal \\
\hline
\end{tabular}

Berdasarkan tabel 8, persentase subjek pada kategori rendah sebesar $0 \%$ atau tidak dijumpainya subjek dalam kategori tersebut. Untuk subjek yang masuk ke dalam kategori sedang berjumlah 15 orang dengan persentase sebesar 33,33\%, dan subjek yang berada dalam kategori tinggi berjumlah 30 orang dengan persentase sebesar 66,67\%. Hasil menunjukkan bahwa sebagian besar subjek berada dalam kategori tinggi, yakni 30

\section{Uji normalitas}

Uji asumsi normalitas dilakukan untuk mengetahui apakah data-data yang diperoleh dari penelitian memiliki distribusi data normal. Uji normalitas dilakukan dengan bantuan SPSS for windows versi 21. Distribusi sebaran data dapat dikatakan normal apabila $p \geq 0,05$. Hasil perhitungan tersebut dapat dilihat pada tabel 9 .

Berdasarkan tabel 10, hasil uji 
Tabel 10. Hasil Uji Linearitas

\begin{tabular}{llll}
\hline \multirow{2}{*}{ Variabel } & \multicolumn{2}{c}{$\mathrm{F}(p)$} & \\
\cline { 2 - 3 } & linearity & $\begin{array}{l}\text { Deviation from } \\
\text { Linearity }\end{array}$ & Keterangan \\
\hline $\begin{array}{l}\text { Kesejahteraan } \\
\text { psikologis dan } \\
\text { daily spiritual } \\
\text { experience }\end{array}$ &, 449 & 0,168 & Linear \\
\hline
\end{tabular}

linearitas antara kesejahteraan psikologis dan daily spiriual experience adalah nilai $\mathrm{F}=0,168$ dan nilai $p=0,005(p<0,01)$. Hasil tersebut menunjukkan bahwa kedua variabel memiliki korelasi yang linear.

\section{Uji hipotesis}

Uji hipotesis dilakukan untuk mengetahui adanya hubungan antara variabel tergantung dan variabel bebas. Dalam penelitian ini yakni kesejahteraan psikologis dan daily spiritual experience. Uji korelasi dalam penelitian ini menggunakan uji korelasi product moment peorson. Hasil perhitungan dapat dilihat pada tabel 11. daily spiritual experience dan kesejahteraan psikologis pada istri yang kehilangan pasangan hidup karena meninggal dunia. Hasil perhitungan diperoleh nilai $r=0,389$, yang berarti terdapat hubungan positif antara daily spiritual experience dan kesejahteraan psikologis istri yang kehilangan pasangan hidup karena meninggal dunia. Tabel 14 juga menunjukkan nilai $\mathrm{r}^{2}$ sebesar 0,152 . Hal tersebut dapat diartikan bahwa 15,2\% dari kesejahteraan psikologis dapat dijelaskan oleh daily spiritual experience. Sedangkan sisanya $84,8 \%$ dapat dipengaruhi oleh variabelvariabel lain yang tidak dimasukkan dalam fokus penelitian. Berdasarkan uraian diatas,

Tabel 11. Uji Hipotesis (Kerelasi Product Moment).

\begin{tabular}{llll}
\hline Variabel & $\mathrm{r}$ & $\mathrm{r}^{2}$ & $p$ \\
\hline Kesejahteraan* & & & \\
$\begin{array}{l}\text { Daily Spiritual } \\
\text { Experience }\end{array}$ & 0,389 & 0,152 & $0,004(\mathrm{p}<0,01)$ \\
\hline
\end{tabular}

Berdasarkan hasil uji hipotesis menggunakan teknik korelasi product moment didapatkat nilai $r$ sebesar 0,389 dengan $p=$ $0,004(p<0,01)$, yang menunjukkan bahwa ada hubungan positif yang sangat signifikan antara maka hipotesis yang diajukan dalam penelitian ini dapat diterima.

\section{Pembahasan}

Penelitian ini dilakukan dengan tujuan 
untuk mengetahui adakah hubungan antara daily spiritual experience dengan kesejahteraan psikologis pada istri yang kehilangan pasangan hidup karena meninggal dunia. Berdasarkan analisis statistik diperoleh nilai $r=0,389$ dan nilai $p=$ $0,004(p<0,01)$. Hasil tersebut menunjukkan bahwa terdapat hubungan postif yang sangat signifikan antara daily spiritual experience dan kesejahteraan psikologis pada subjek penelitian, yakni istri yang kehilangan pasangan hidup karena meninggal dunia. Hal ini dapat dimaknai bahwa semakin tinggi daily spiritual experience, maka semakin tinggi pula kesejahteraan psikologis istriyang kehilangan pasangan hidupnya. Begitu pula sebaliknya, semakin rendah daily spiritual experience, maka semakin rendah pula kesejahteraan psikologis istri yang kehilangan pasangan hidupnya. Apabila istri yang kehilangan pasangan hidupnya karena meninggal dunia memiliki daily spiritual experience yang tinggi, maka istri akan mampu mengontrol diri dan lingkungan, lebih mandiri serta memiliki penerimaan diri dan tujuan hidup yang baik.

Individu yang memiliki daily spiritual experience dalam diri, memiliki penghargaan terhadap nilai-nilai transeden dan makna hidup, sepetri rasa kebersyukuran, keutuhan, kasih sayang, belas kasihan dan lain sebagainya (Underwood, 2006). Di dalam Alquran dijelaskan bahwa bahwa agama dan keyakinan terhadap-Nya mengandung unsur yang membantu individu dalam mengatur hubungan manusia dengan sesama manusia dan hubungan manusia dengan lainnya, sesuai dan sejalan dengan tata keimanan. Salah satunya dijelaskan dalam Alquran, surah Al-Hujurat ayat 11: Hai orang-orang yang beriman, janganlah sekumpulan orang laki-laki merendahkan kumpulan yang lain, boleh jadi yang ditertawakan itu lebih baik dari mereka. Dan jangan pula sekumpulan perempuan merendahkan kumpulan lainnya, boleh jadi yang direndahkan itu lebih baik. Dan janganlah suka mencela dirimu sendiri dan jangan memanggil dengan gelaran yang mengandung ejekan. Seburuk-buruk panggilan adalah (panggilan) yang buruk sesudah iman dan barangsiapa yang tidak bertobat, maka mereka itulah orang-orang yang zalim.

Tuntunan yang terdapat di dalam Alquran membatu seseorang dalam menjaga hubungan baik dengan sesama manusia dan lingkungan sekitarnya serta dapat hidup lebih terarah dengan adanya persepsi dan emosi positif yang terkait dengan aspek transpersonal. Hal tersebut sejalan dengan kesejahteraan psikologis. Seseorang yang memiliki kesejahteraan psikologis yang tinggi, akan memilki kemampuan dalam menjalin hubungan yang positif dengan orang lain, mampu menguasai lingkungan serta memiliki tujuan hidup yang positif (Ryff, 1989).

Terdapat banyak faktor yang dapat 
mempengaruhi kesejahteraan psikologis, salah satu dari faktor tersebut adalah spiritualitas (Wink \& Dillon, 2004). Dijelaskan oleh Jafari et al. (2010) bahwa keyakinan dan penghargaan atas nilai-nilai spiritual dalam diri seseorang menciptakan kekuatan yang dapat mempengaruhi postur fisik, perasaan, pikiran dan komunikasi dan akan memberikan efek perlindungan dalam melawan stress serta mengarahkan seseorang pada cara hidup yang lebih sehat, penuh tujuan dan harapan yang bermakna. Diperkuat juga oleh penelitian yang dilakukan oleh Basya (Putri, 2012) yang menjelaskan bahwa kebahagian seseorang terdapat dalam ketaataannya kepada Tuhan, kecintaannya terhadap sesama serta menolong dan mengasihi orang lain yang membutuhkan pertolongan.

Istri yang kehilangan pasangan hidupnya akibat meninggal dunia cenderung mengalami perasaan tidak berdaya, kecemasan dan kesedihan bahkan depresi yang menimbulkan ketidakbahagiaan (Nalungwe, 2009). Dijelaskan oleh Underwod dan Teresi (2002), bahwa sebuah penelitian di Chicago menunjukkan bahwa terdapat hubungan negatif yang signifikan antara daily spiritual experience dengan kecemasan dan depresi. Hal ini dapat dimaknai bahwa individu dengan daily spiritual experience yang baik, maka akan memiliki tingkat tingkat kecemasan dan depresi yang lebih rendah. Sebaliknya, apabila individu memiliki daily spiritual experience yang rendah, maka akan memiliki tingkat kecemasan dan depresi yang tinggi pula. Oleh karena itu, dengan memiliki daily spiritual experience dalam diri, istri yang kehilangan pasangan hidupnya dapat terhindar atau keluar dari perasaan cemas dan depresi yang berlarut-larut pasca kematian suami sehingga dapat bangkit lebih cepat untuk menggapai kebahagiaan yang diinginkan. Penelitian lainnya juga menjelaskan bahwa daily spiritual experience memiliki hubungan positif yang signifikan dengan kualitas hidup, optimisme dan perilaku prososial (Underwood \& Teresi, 2002).

Agama memegang peranan penting dalam kehidupan seseorang dan tercermin dengan adanya keyakinan dan kepercayaan kepada Tuhan. Agama akan memberikan bimbingan dan tuntunan yang sebaik-baiknya kepada individu yang mengimaninya. Sesuai dengan yang dijelaskan Allah dalam AlQur'an bahwa agama dan kitab suci Al-Qur'an akan membawa seseorang kepada kebenaran. Selain itu, seseorang yang selalu percaya bahwa Allah adalah Yang Maha Mengasihi dan Menyayang, maka akan senantiasa dituntun dalam menghadapi segala macam masalah dalam kehidupan. Selain itu, individu juga akan percaya bahwa masalah merupakan ujian dari Allah SAW dan akan diikuti hikmah yang baik dibaliknya.

Penelitian ini menunjukkan bahwa daily spiritual experience dapat digunakan 
sebagai prediktor tinggi rendahnya kesejahteraan psikologis pada istri yang kehilangan pasangan hidup karena meninggal dunia, dengan sumbangan efektif antara daily spiritual experience dan kesejahteraan psikologis sebesar 0,152. Artinya bahhwa daily spiritual experience memberikan sumbangan efektif terhadap kesejahteraan psikologis sebesar 15,2\%.

Dilihat dari level pendidikan, hasil analisis statistik menunjukkan tidak terdapat perbedaan kesejahteraan psikologis antara subjek dengan pendidikan terakhir Sekolah Dasar (SD) dan subjek dengan pendidikan terakhir Sekolah Menengah Pertama (SMP) hingga perguruan tinggi, dengan nilai t sebesar 0,979 dan nilai $p$ sebesar 0,333 ( $p>0,05)$. Venhonven dan Bakker (1979) menjelaskan bahwa pengaruh level pendidikan terhadap kesejahteraan psikologis seseorang bergantung pada usia, jenis kelamin, fungsi sosial dan status sosial ekonomi. Level pendidikan berpengaruh secara signifikan pada kesejahteraan psikologis hanya pada orang dewasa muda. Selain itu, hasil analisis juga menunjukkan bahwa tidak terdapat perbedaan kesejahteraan psikologis istri yang kehilangan pasangan hidup karena meninggal dunia berdasakan pekerjaan, baik sebagai petani, maupun pekerjaan lainnya, seperti pegawai negeri sipil, pegawai swasta, wirausaha dan ibu rumah tangga. Hal ini terjadi karena jenis pekerjaan tidak perngaruh pada kesejahteraan psikologis seseorang, melainkan faktor-faktor subjektif yang berkaitan dengan pekerjaan tersebut, seperti rasa cinta terhadap pekerjaan, perasaan nyaman dalam menjalani pekerjaan, hubungan baik dengan orangorang dilingkungan tempat bekerja dan lain sebagainya (Stolk, Hofman \& Hafner, 2014).

Dalam penelitian ini, responden penelitian memiliki daily spiritual experience yang tinggi $(66,67 \%)$ dan kesejahteraan psikologis yang tinggi pula $(66,67 \%)$. Hal tersebut dapat diinterpretasikan bahwa kesejahteraan psikologis yang tinggi pada responden penelitian terkait dengan daily spiritual experience yang tinggi. Daily spiritual experience atau persepsi dan emosi positif terkait dengan dimensi transpersonal yang tinggi membuat responden penelitian, yakni istri yang kehilangan pasangan hidup karena meninggal dunia mempu keluar dari perasaan terpuruk pasca kematian suami dan mampu menyelesaikan masalah-masalah yang muncul dengan baik, sehingga memiliki kesejahteraan psikologis yang baik pula.

\section{Simpulan}

Berdasakan hasil penelitian dan analisa data, maka diperoleh kesimpulan bahwa ada korelasi positif yang signifikan antara daily spiritual experience dan kesejahteraan psikologis pada istri yang kehilangan pasangan hidup akibat 
meninggal dunia. Hal tersebut dapat diartikan bahwa semakin tinggi daily spiritual experience, maka semakin tinggi pula kesejahteraan psikologis pada istri yang kehilangan pasangan hidup akibat meninggal dunia. Begitu pula sebaliknya, semakin rendah daily spiritual experience, maka semakin rendah pula kesejahteraan psikologis pada istri yang kehilangan pasangan hidupnya akibat meninggal dunia.

\section{Saran}

Berdasarkan hasil penelitian dan pembahasan, maka peneliti mengemukakan beberapa saran, yaitu:

Subjek penelitian hendaknya terus meningkatkan atau menjaga daily spiritual experience yang dimiliki sebagai sebuah langkah untuk mencapai kesejahteraan psikologis yang tinggi. Sebaiknya istri yang kehilangan pasangan hidupnya lebih mendekatkan diri kepada Tuhan, sehingga dapat membantu dalam memghadapi masalah-masalah pasca kematian suami dan terhindar dari stress dan depresi yang berkepanjangan.Penelitian selanjutnya yang ingin mengangkat topik kesejahteraan psikologis dilakukan dengan mengaitkan variabel tersebut dengan dengan topik-topik islami lainnya yang juga belum banyak diteliti di dalam maupun luar negeri, seperti ridho, ikhlas dan topik lainnya. Penelitian selanjutnya dapat mencoba desain penelitian kualitatif atau eksperimen agar data yang didapat lebih detail dan mendalam. Dengan dua metode tersebut daily spiritual experience seseorang akan jauh lebih terlihat. Penelitian selanjutnya perlu mempertimbangkan penggunaan alat ukur versi pendek atau panjang dengan baik, untuk menghindari kelayakan alat ukur yang rendah karena banyaknya aitem yang gugur. Selain itu, peneliti selanjutnya juga perlu memperhatikan tata bahasa yang baik saat mengubah alat ukur asli kedalam versi bahasa Indonesia, agar kemungkinan aitem yang gugur semakin rendah. Penelitian selanjutnya hendaknya untuk tidak hanya sekedar menerjemahkan alat ukur ke dalam versi bahasa indonesia, namun juga menyesuaikan dengan konteks penelitian, seperti menyesuaikan alat ukur dengan karateristik-karektiristik subjek dalam penelitian yang dilakukan. Penelitian selanjutnya yang menggunakan subjek istri yang kehilangan pasangan hidup karena meninggal dunia perlu memperbanyak dan memperkaya data-data mengenai subjek penelitian, seperti pekerjaan suami, jumlah anak, sebab meninggal, lama waktu meninggalnya suami, lama menikah dan keterangan terkait aktivitas ibadah harian. sehingga data-data tersebut dapat dipergunakan sebagai penguat latar belakang masalah dan alasan pemilihan judul. 


\section{Daftar Pustaka}

Azwar, S. (2009). Penyusunan Skala Psikologi. Yogyakarta: Pustaka Pelajar.

Departemen Agama RI. (1976). Alquran dan Tarjemahannya. Jakarta: Bumi Restu.

Doshi, D.R., \& Yogesh, A.J. (2013). Depression and psychological well-being in old age. Psychol Psychother, 3.117.

Einolf, C. J. (2013). Daily spiritual experiences and prosocial behavior. Social Indicators Research, 110(1), 71-87.

Jafari, E., Dehshiri, G.R., Hosein, E., et al. (2010). Spiritual well-being and mental health in university students. Rocedia Social and Behavioral Sciences, 5, 1477-1481.

Laksono, A.R. (2008). Pemecahan masalah pada wanita sebagai orang tua tunggal. Skripsi. Fakultas Psikologi Universitas Muhammadiyah Surakarta.

Nalungwe, P. (2009). Loneliness among ederly widows and it's effect on their mental well being. Thesis: Laurea University of Applied Sciences.

Ryff, C.D., \& Keyes, C.L. (1995). The structure of psychological well-being revised. Journal of Personality and Social Psychology, 69, 719-727.

Ryff, C.D. (1995). Psychological well being in adult life. Current Dirrections in Psychological Sciences, 4, 99-104. h t tp / / dx:doi.10.1111/14678721.ep10772395.

Ryff, C.D. (1989). Happiness is everything or is it? Explorations on the meaning of psychological well being. Journal of
Personality and Social Pyschology, 57, $\begin{array}{llllllllll}1 & 0 & 6 & 9 & - & 1 & 0 & 8 & 1\end{array}$. http / / dx:doi.10.1037/00223514.57.6.1069.

Santrock W. J. (2003). Life Span Development, Boston: McGraww Hill College.

Stolk, C., Hofman, J., Hafner, M., Janta, B. (2014). Psychological well being and Work. Social Science in Goverment: Europe

Underwood, L.G. (2006). Ordinary spiritual experience: Qualitative research, interpretive guidelines, and population distribution for the daily spiritual experience scale. Archive for the Psychology of Religion, 28, 181-218. http//dx:doi.10.1163/008467206777 832562.

Underwood, L.G., \& Teresi, J. A. (2002). The daily spiritual experience scale: development, theoretical description, reliability, exploratory factor analysis, and preliminary construct validity using health-related data. Annals of behavioral medicine : a publication of the Society of Behavioral Medicine, 24, 22-33. http//dx:doi.10.1207/s15324796abm 2401_04.

Venhonveen, R., \& Bakker, P. (1977). Level of Education and Psychological Well Being. Departement of Sociology: Eramus University Roterdam

Wilcox, S., Evenson, K., Aragaki, A., Smoller, S.W., Mouton, C.P., \& Loevinger, B.L. (2003). The effects of widowhood on physical and mental health, health behaviors, and health outcomes: The women's health initiative. Health Psychology, 22, 513-522. 
Wink, P., \& Dillon, M. (2003). Religiousitas, sprituality, and psychological functioning in late adulthood: Findings from a longitudinal study. Psychological and Aging, 18, 916-249. 